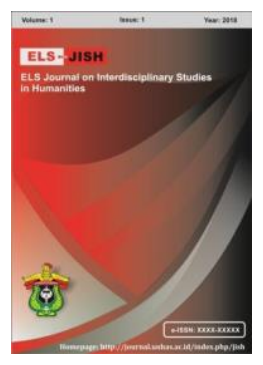

ELS-JISH

ELS Journal on Interdisciplinary Studies on Humanities

Volume 3 Issue 3, 2020

ISSN (print) : 2621-0843

ISSN (online) : 2621-0835

Homepage : http://journal.unhas.ac.id/index.php/jish

\title{
The Racist Fact against American-Indians in Steinbeck's The Pearl
}

\author{
Abbas $^{1}$ \\ abbasr@unhas.ac.id
}

\begin{abstract}
This article is American literary research that aims to explore the social conditions of Indians as Native Americans for the treatment of white people who are immigrants from Europe in America. This research explores aspects of the reality of Indian relations with European immigrants in America that have an impact on discriminatory actions against Indians in John Steinbeck's novel The Pearl. Social facts are traced through fiction as part of the genetics of literary works. The research method used is genetic structuralism, a literary research method that traces the origin of the author's imagination in his fiction. The imagination is considered a social reality that reflects events in people's lives. The research data consist of primary data in the form of literary works, and secondary data are some references that document the background of the author's life and social reality. The results of this research indicate that racist acts as part of American social facts are documented in literary works. The situation of poor Indians and displaced people in slums is a social fact witnessed by John Steinbeck as the author of the novel The Pearl through an Indian fictional character named Kino. Racism is an act of white sentiment that discriminates against Native Americans, namely the Indian community.
\end{abstract}

Keywords: Racism, America, Genetic Structuralism, Novel The Pearl.

How to cite: Abbas, A. (2020). The Racist Fact against American Indians in Steinbeck's The Pearl. ELS-Journal on Interdisciplinary Studies in Humanities, 3 (3), 393-407. DOI: https://doi.org/10.34050/elsjish.v3i3.11347

\section{Introduction}

For thousands of years, humankind in this world has built a variety of great civilizations that are always followed by oppression. The great civilization of the Pharaoh in Egypt that lasted around three thousand years has been investigated by historians and archeologists to oppress the Nation of Israel. The Egyptians treated the racists of the Israelites by carrying out murders, slavery, torture, and deprivation until they were released by the Prophet Moses about 3000 years BC. Al-Hafiz (2012: 265), in his research, described that Egyptian rulers with the title of Pharaoh or Ramses ordered the killing of Israeli children and threw them into the Nile. This action took place as a racist attitude that discriminates against a particular nation in building civilization.

\footnotetext{
${ }^{1}$ Hasanuddin University, Indonesia.
} 
Racist acts were also carried out by a number of other great civilizations that grew since BC, including Babylon, Mesopotamia, Sumerian, Hindustan, Rome, and others. Persecution and racism continue to be carried out by some major civilizations in the post-Christian era such as Mongolia, namely the ferocity of the Tartars who invaded, seized, killed, and destroyed the cultures of other nations ranging from Asia, the Middle East, Africa, and Europe. Racists were also shown by Europeans when the Spanish, Portuguese, English, Italian, French, Dutch and German empires expanded, colonized and exploited some nations and ethnicities in the Americas, Asia and Africa in the Middle Ages to the outbreaks of World Wars I and II.

The expedition of some kingdoms in Europe against America began when Christopher Columbus who carried the mission of Queen Isabella in Spain, landed in the Caribbean. Then the expedition followed by Juan Ponce de Leon of Portugal who arrived in Florida in 1513. He subsequently and successively arrived in America. Amerigo Vespucci from Italy arrived on the American Atlantic coast in 1529. Jacques Cartier from France arrived at the Lawrence River in 1534, Humphrey Gilbert and Walter Raleigh founded the first British Colony in North Carolina in 1585, Henry Hudson of the Netherlands built a settlement in New York City in 1609. A century later, there were also Germans, Norwegians, Danes, Swedes, and Russians. This European relationship with Native Americans, namely Indians, initially took place well in the form of trade and commodity exchange. However, this relationship then deteriorated and became a conflict when European settlers wanted to control the assets and commodities of the people Indian.

The good relations between the Europeans and the Indians eventually turned into hostile actions and became racist sentiments for hundreds of years. Indians who discriminated against began to make a move against the colonization of the land and trying to protect their culture. According to Cineotta (2004: 22-24), the Indians made their first resistance in Virginia in 1622 and 1637 when they prevented the formation of English settlements in Virginia and Connecticut. The Indians were increasingly forced to leave their territories and fled inland, many of whom were eventually made slaves by immigrants from Europe.

The racist problem in America has been a humanitarian issue since the Indians built a collective awareness to obtain justice for their rights and equality in social interaction. Various forms of resistance are carried out by Indians and writers who sympathize with their conditions. One of the authors who perpetuated the fate of the Indians until the twentieth century was John Steinbeck in his novel called The Pearl. This novel tells the story of an Indian family named Kino who was treated discriminatively by Europeans in La Paz, California. Racist sentiment towards them remained a severe problem in the social life of Americans until after World War II.

The central part of the discussion of the article as well as the purpose of this research can be seen from two aspects; first, literature as a social document, and secondly, the science of literature can be used in tracing fictional genetics. The first aspect is intended to uncover discriminatory, racist acts and oppression of Indians as an American social fact reflected in the novel The Pearl. Then the second aspect is to strengthen the scientific theory of literature that literary works 
are not just fiction. However, they have sociological elements related to reality in aspects of human life. The article is expected to be useful for literary reviewers and literary readers that literary works are imaginative works that have a universal element that records events that have existed in certain people's lives. Based on the aims and benefits intended in this study, the writer formulated the title of this article, namely Racist Facts against American Indians in John Steinbeck's The Pearl.

\section{Method}

\subsection{Theoretical Framework}

The research issue of this article is racist in literary works by compiling a number of sociological literary theories that carry racist studies. The word sociology comes from Ancient Greek, namely socius means collection together, and logos means knowledge or science. Socius in English then becomes a society that means people or community, while logos becomes science which is interpreted as empirical rationality of knowledge. Then the literary word comes from the syllable sas meaning to teach and tra means a tool which is Sanskrit. Literature can be categorized as the work of an imaginative author who teaches humans to live ethically, morally, and in character. So the relationship between sociology and literature can be understood as a reflection of social problems in human life or society that foster human awareness of life experiences that teach goodness in the literary works.

According to Fathu Rahman (2018:149-172), literature has a high status in a civilized community. It means that literary work should be respected as a product of society. Ratna (2013: 238-244), literary texts have sociological symbols as a reality that transcends the context of the story. It means that phenomena that occur in literature have facts that occur outside of the fiction. The facts referred to here are real events that took place in the community whose important parts are documented in literary stories. Social facts in literature are considered as the origin of the creation of literary works by their authors. Documenting social facts in literature became one of the issues in the sociological study of literature. Sociological issues in the literature include slavery, racism, coercion, gender discrimination, feminism, social injustice, deprivation of human rights, economic exploitation, and others.

One of the sociological perspectives of literature is racist issues. This issue is an essential part of the history of the American Nation, some of which are documented in the literature. According to Roger Sell in Goring, et al. (2001: 174), literary stories are actually community communication absorbed from certain sources so that the source of the author's imagination is an important thing to be explored by researchers and literary readers. So, the discriminatory acts that befell the Indians in the novel The Pearl. It cannot be separated from the life experience of John Steinbeck who witnessed the suffering of the Indians in America as a source of his imagination. He also understood the historicity of the sentimental relationship between European immigrants and Indians as Native Americans.

This research traces racist facts in the literary work entitled The Pearl by John Steinbeck so that the sociological theory used is racism. According to 
Farkhan (2020), conflicts can be caused by cultural, racist, and ethnic entity issues. It shows that racist actions inevitably cause conflict as a result of adverse ethnic attitudes towards other ethnic groups. The attitude that was initially friendly then turned into an act of coercion, deprivation, fraud, discrimination, exploitation, and soon, then this friendly relationship can turn into hostility. Forms of hostility can take the form of personal conflicts, group conflicts, and political conflicts. This view shows that racist actions create hostility with sentimentality, which can ultimately create wars between ethnic groups.

Racism is a matter of treatment and attitudes that harm certain groups. Racist action becomes a big problem if it is done by a ruling group that controls aspects of people's lives in the political, educational, economic, and others. In situations like this, racist acts become oppressive, where the oppressed groups will hold grudges to the next generation can even last for hundreds to thousands of years. Campbell (2018) argues that rebellion can be carried out by groups that are racist treated against the ruling group if there is a deadlock in the dialogue. The Indians fought several times with the government in America from 1622 to 1900 because negotiations always failed and violations of the constitution continued and the racial sentiment was still felt in the social life of the people.

Racist attitudes take place in two categories, namely individuals and the constitution. An individual's racist attitude is a personal sentiment towards another person or group that treats them differently and adversely. For example, when a doctor with a white ethnic refused to treat an Indian patient because of his sentiments towards the Indians, the doctor's actions were categorized as racist individuals. The constitutional racism took place at the behest of the authorities legalized in regulations; for example, the American government in 1812 legalized the expulsion of the Indians from their lands in the Indian cultural conservation area which resulted in racial sentiment. Institutional actions like this according to the human rights institutions of Alberta Civil Liberties Research Center (2018) can have a systemic and massive impact because the treatment of violence is politically and constitutionally set.

Based on various explanations about racism, it can be seen that racism is a treatment that distinguishes one's position from others or places social classes based on race and skin color that harm certain groups. The theoretical framework used in this study is literary sociology that describes the racist treatment of the Indians in America in John Steinbeck's novel The Pearl.

\subsection{Research Methodology}

The method used in this research is Genetic Structuralism, one of the approaches in sociological-based literary studies. This study method emphasizes the origins of the creation of literary works as the genetics of fiction. Literary genetics are seen as imitations of the conditions of society. In the mimesis theory put forward by Aristotle in Ancient Greek times is said that literary works are imitations of reality that occur in people's lives. An imitation can be likened to a picture of a mountain in painting because in the universe there is a mountain, the flower in the painting is an imitation of a flower in the real world. Likewise, the story of slavery in Uncle Tom's Cabin novel is due to the fact of slavery in America 
against Negroes by white people, or the racist against American Indians in the fictional story of The Pearl reflected from the social condition of Native Americans.

According to Faruk (2014: 56-62), the Genetic Structuralism Approach was made a literary research model by Lucien Goldmann built on Taine's sociological thinking. According to Goldmann (1977: 15-20), literary works are created through the imaginative process of the author, who consciously creates literary works from an in-depth study of the reality that occurs in the surrounding community. This reality becomes the author's source of inspiration in building his imaginary world which eventually turns into fiction. The author requires a long time to interact with the community to produce an issue in his fiction. The issue is called worldview or vision du monde.

Referring to the relationship of sociology with literature, literary works are created from a sociological process. Goldmann (1981: 10-15) views that literature is social documentation so that the origin of literary works comes from the structure of society and the results of human adaptation to the environment. The three main elements in the Genetic Structuralism research method are the literary structure, author's social background, and social reality. The process of literary creation starts from an author's experience and knowledge of certain conditions in society as a social reality. The author then processes reality into his imagination. The author then manifests his imagination in the form of literary works that carry universal values.

Based on genetic structuralism research methods, the data source is divided into two, namely primary data and secondary data. The racist issue in John Steinbeck's The Pearl by the primary source of data is seen as a fact in the history of American society regarding the discriminatory treatment of Indians. This fact is a universal value called vision du monde or world view. Then a number of information that includes the author's social background and racist facts against the Indians as the genetics of the literary works studied are secondary data, including references in the form of An Outline of American History (1992) and Outline of American History (2004).

Primary and secondary research data processing refers to the research formulation of genetic structuralism proposed by Endraswara (2013: 60-63), which is three stages to find vision du monde or world view. The first is to examine the intrinsic elements of literary works as a mutually structured story structure. The second is to explore the author's background of social life related to his imagination journey in literary works. The third is to reveal the social and historical facts of society that underlie certain issues in literary work. Reconstruction of all of these steps can be seen in Chart 1: 
Chart 1. Formulation of Genetic Structuralism

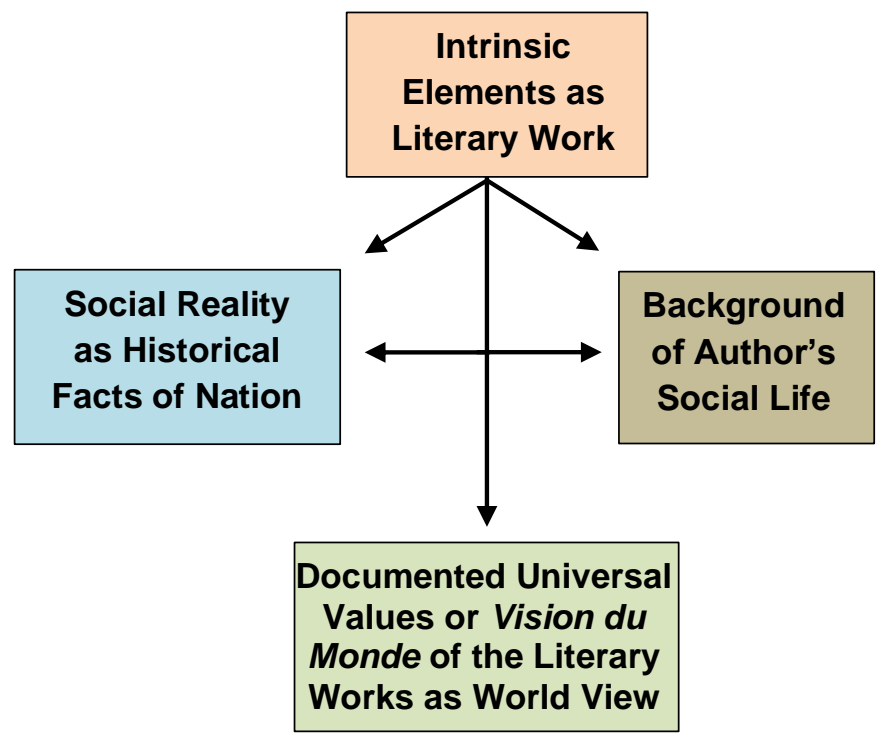

In Chart 1, the writer integrates into this stage of the study, which examines the fact of the racist treatment of Indians in America as a reflection of John Steinbeck's novel The Pearl. The first step is to study the intrinsic elements of literary works in the form of descriptions of The Pearl novel. The second stage is to trace the background of the author's social life in documenting the social conditions of the Indians as part of the social background of John Steinbeck. The third is to reveal the racist facts of Indians in the racist history of the American Nation. The sociological relationship between The Pearl's imaginative story with the background of John Steinbeck's life and the social realities of the Indians produce literary genetics as a vision du monde or world view, namely the reality of American Indian racism in John Steinbeck's The Pearl. This shows that in fiction, documented facts that teach humans the need for goodness and ethics.

\section{Discussion}

As the literary research procedure on the Genetic Structuralism Approach has been explained, the first step is to describe the novel The Pearl. Then to explore the social background of John Steinbeck, the next issue of racist Indians as a social reality, and finally the racist documentation of the American Indians on novel The Pearl as universal values.

\subsection{Description of the Novel The Pearl}

Novel The Pearl tells of the racist treatment which befell Native Americans by descendants of European immigrants in America. Discrimination occurs because of differences in race and skin color between white Celtic French people and Indians from the brown Mongoloid race. White people live in luxury, domiciled, educated, powerful, and have other social access, whereas brown people live in poverty, have no access to education and other social aspects even though they are indigenous people. This fiction takes place around the 1940s in the western South American region in the city of La Paz, the city of Loreto, Santa Rosalina, Cape California, and several other physical settings. 
The Indians, including Kino and his wife named Juana and their baby named Coyotito, live in the coastal area of Cape California near the city of La Paz. They live as fishermen looking for fish, shellfish, and pearls. The descendants of European immigrants living in the city of La Paz viewed the Indians as low class and treated them unfairly and even carried out discriminatory acts as the doctor said, "Have I nothing better to do than cure insect bites for 'little Indian'? I am a doctor, not veterinary" (Steinbeck, 1962: 14).

One day Kino and Juana took Coyotito, who was stung by a scorpion, to a French doctor in the city of La Paz. The doctor refused to treat Coyotito because this baby came from an Indian family. The doctor arrogantly did not want to see Kino with various sentimental reasons, including Kino was an Indian, poor man, he did not deserve treatment and came from a slum. The doctor then told his servant to close the door and expel Kino. Getting hurt, Kino and his wife could only stand in front of the fence feeling angry and angry, he punched the fence, "For a long time Kino stood in front of the gate with Juana beside him. Slowly he put his suppliant hat on his head. Then, without warning, he struck the gate a crushing blow with his fist. He looked down in wonder at his split knuckles and at the blood that flowed down between his fingers" (Steinbeck, 1962: 16).

Kino and Juana brought their baby back home with disappointment, upset, hurt, and angry. This event led to a realization that education and economics were guarantees that the Indians would be free from discriminatory treatment. Kino was determined to work hard so that he could later send Coyotito to school. His son became the foundation of hope in changing the state of his life for the better in the future. He thought that future generations of Indians had to go to school to be smart. Therefore they would no longer be treated unfairly by white people. Indian children became the foundation of hope that freed the Indians from oppression, "My son will read and open the books, and my son will write and will know writing... and these will make us free..." (Steinbeck, 1962: 33).

Kino finally found a large pearl that he believed was expensive. Since Kino found the pearl, white people from the city including the doctor came to see him and pretended to be kind to him with various offers of kindness. They wanted to buy cheap pearls, but Kino did not want to sell to those who were cunning and swindlers. He persisted in his belief that pearls were expensive. He has a dream of wanting to send his son to school from the sale of his pearls. He was determined to go far to reach large cities to find buyers who could buy pearls at high prices. White people in the city of La Paz conspired that the pearl were cheap, but Kino still refused their evil plans. He finally took Juana and Coyotito away to sell their pearls at high prices in other cities.

White people hired robbers to snatch Kino's pearl so he would not go anywhere else to sell his pearl. Along the way, Kino was intercepted by several armed robbers. At the end of the story, Kino managed to kill the robbers, but he also lost his pearl and baby. Coyotito died because he was not treated by the scorpion sting poisoning. He then threw away his pearl and returned to his hometown, but he found his house had been burned by robbers. Kino was tired, he failed to change the fate of the Indians. 


\subsection{The Social Background of John Steinbeck}

In this section, the writer explores the background of John Steinbeck's life about racist discrimination that befell the Indians. John Steinbeck was born in the City of Salinas, Cape California on February 27, 1902. His mother named Olive Hamilton came from Northern Ireland and his father's family came from Germany. The family of his mother and father arrived in America around the 1850s. Steinbeck's life is lived in many parts of southern America such as Salinas, California, Arizona, Texas, New Mexico, and Oklahoma. Racist sentiment remained strong in this region until the twentieth century, although the equality of all Americans is the same without racial differences and skin color set in the American Constitution Amendment XV of 1869. He witnessed many racist events that befell the native Indians and people black Negroes.

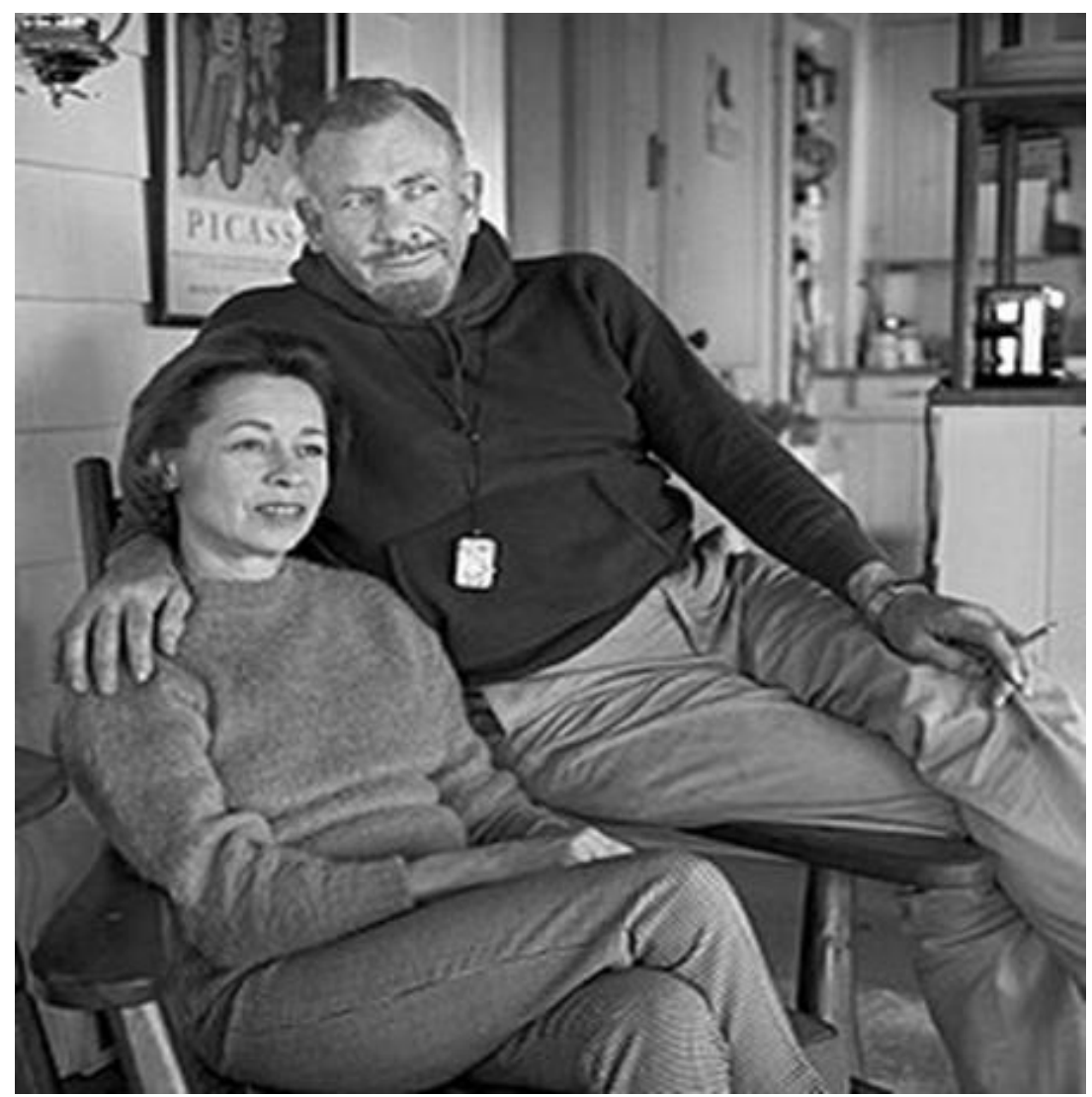

Picture 1. John Steinbeck met Elaine Scott in 1949 at a restaurant in Carmell, California and married in December 1950. (Source: https://en.wikipedia.org/wiki/John Steinbeck accessed on April 13, 2020 at 09.32)

From elementary school through college at Stanford University, John Steinbeck disliked memorization and was more interested in writing essays. He did not finish his studies in the university and then went to livestock, then worked in a chemical factory, then became a laborer at the Spreckles Sugar Factory, then worked on a farm in the Salinas Valley. He also worked as a construction worker and a mining worker. During this various types of work, he witnessed the suffering of the Indians who became laborers such as hunger, poverty, misery, and ignorance which documented in his first novel entitled A Cup of Gold in 1929. 
Steinbeck was well aware of the social conditions of Indians and Negroes who were still considered racist by whites. He was saddened to see the fate of the Indians whose land was being seized by European immigrants. They opened up agricultural land and agriculture also mining, then they abandoned the Indians as the indigenous people. Pearson (1994: 306) described Steinbeck's testimony to the Indians that their lands were diminishing and displaced out of town so they lived in slums, now they were starving even though they had never been hungry. The Indians tried to pacify the hearts while surviving and witnessed the immigrants live in wealth and luxury. Steinbeck continued to build his critical spirit on social reality in several literary works until he died in Salinas on December 30, 1968.

\subsection{American Racism}

Those who were treated racist by white people in America were native Indians who were brown and black Negro slaves. The writer only explains the Indian social facts related to racism because Negroes are more dominated by the issue of slavery. Indians as natives in America began to clash with Europeans as immigrants in 1622 in Virginia, then continued on the Connecticut River in 1637, then the conflict spread to New Mexico, New York, Pennsylvania, and others. When Britain united 13 of its colonies of America in a region called New England in 1685, indigenous people from 5 tribes also formed a government called HoDe-No-Sau-Nee or the Iroquois League. Conflict can be temporarily mitigated by limiting the area of British and European settlers on the east coast of America, while the western regions in the Rocky Mountains, Appalachian, Black Hills, etc., become a customary and cultural conservation area of the Indians.

After the American Revolution was completed in 1789, the white population increased so that they expanded residential areas and arable land into Indian conservation areas which resulted in a war in 1812. Large-scale immigration into Indian's territory took place which according to Olson (1992: 73-74), the white people annexed the territory covering an area of 7.8 million square kilometers. Through the Indian Removal Act passed by Congress, the American Government expels Indians so they are forced to walk to the southern and western tip of America. They left the land of their ancestors that they have inhabited for thousands of years. During the journey of hundreds to thousands of kilometers, they experienced great suffering in the form of fatigue, hunger, and illness that caused many of them to die. This tragic Indian trail is perpetuated as a very sad event termed the Trail of Tears in American history.

The main reason white people are competing to break into the Mississippi, Nevada, Montana, Colorado, Wyoming, Dakota, Idaho, Kansas, Nebraska, California, and others is because this area is a good pasture to be used as a livestock area and agriculture, also found gold, silver, iron, coal mines there. They explore and exploit these conservation areas. The Indians were increasingly eliminated from their homeland with very poor social conditions. They are treated inhumanely, racist, slaughtered, expelled, and relocated to slums. The last resistance of the Indians occurred in 1890. The American government through the Dawes Act of 1887 again divided the indigenous land of the Indians to white families such as each family obtained an area of 65 hectares. 


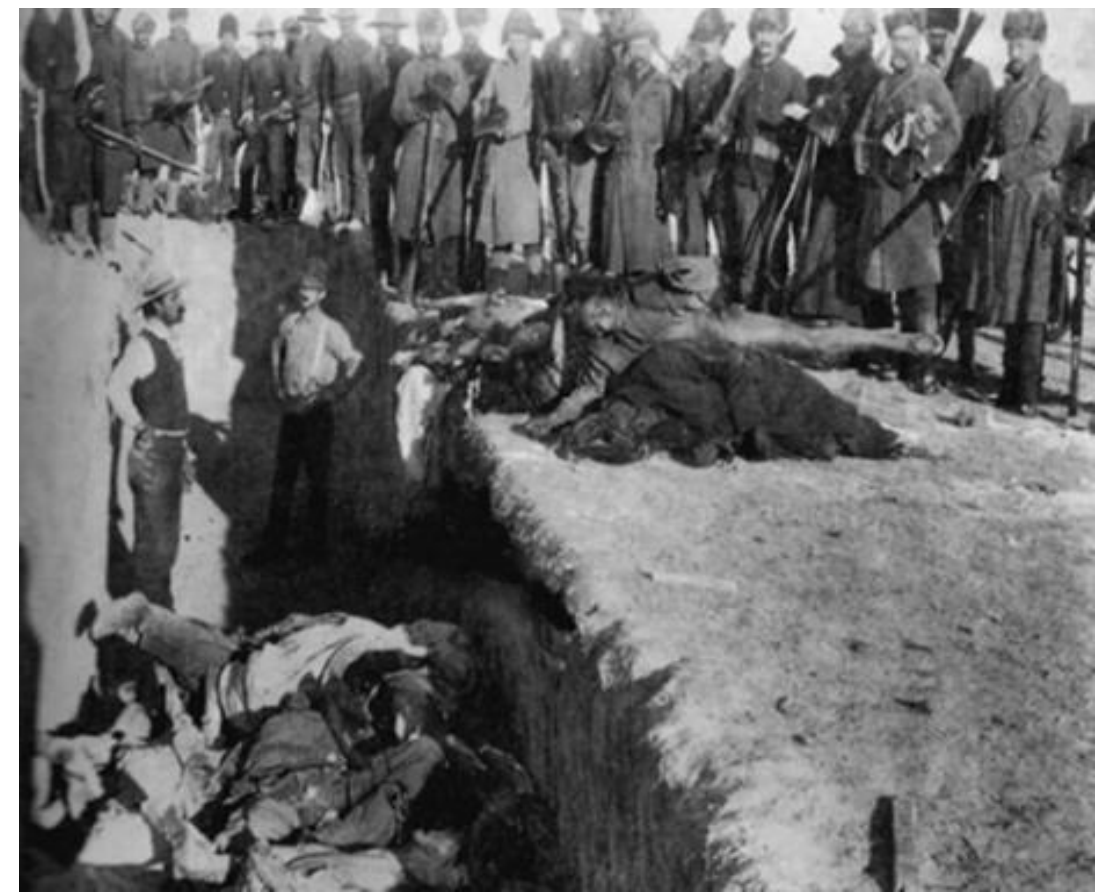

Picture 2. The burial of Indians killed in the massacre of the Wounded Knee in the late 1880s.

(Source: https://www.matamatapolitik.com/historical-genosida-sukuindian-pembantaian-penduduk-asli-amerika-atas-nama-peradaban/ accessed on April 14, 2020 at 10.30 p.m.)

The alarming oppression of Indians has drawn criticism from reformers such as Helen Hunt Jackson. He wants them to be assimilated and protected by their communal rights as was done in Carlisle, Pennsylvania. The American government according to Cineotta (2004: 215-217) was forced to reform Indians through the Indian Reorganization Act of 1934. The law protected Indian tribal organizations and preserved traditional Indian culture. Assimilation of the Indians is a complicated problem for the American Government because they find the Indians difficult to adapt to heterogeneous and individualistic advanced civilizations. Even though they are protected by law, there are still white people who are racist in their minds to them.

\subsection{The Reality of American Indian Racism in John Steinbeck's The Pearl}

In this section, the writer explored the reflection of social reality or the mirror of the situation of American society against the fictional story of The Pearl by John Steinbeck as a documentation of universal values in literary works. Social conflict is part of the history of the American people towards national stability as is enjoyed today. One of the biggest conflicts that occur is the problem of racism that is commonly experienced by brown Indians and black Negroes, but in this article focused more on the issue of racism against Indians as a genetic reality in this fiction. Since the early arrival of Europeans in America, white people have been in conflict with Indians as happened in Virginia in 1622, Connecticut in 1637, and elsewhere. According to Larasati (2019), the conflict was triggered by the 
many differences between European immigrants and Indians, including language, culture, beliefs, rituals, perspectives, and skin color. The Indians kidnapped a girl named Mary Campbell in Pennsylvania in 1753 and were considered barbaric by white people.

The conflict continued in the form of war as it did in 1812 until the last war occurred in 1890. During this time, the Indians fought to protect their communities, homeland, and culture from the genocide of American militias and military. Conflicts and massacres carried out by American militias and military on several occasions, including the murder in Delaware in 1782, the dispute in Indiana in 1811, the Muskogee Creek war 1813-1814, forced evictions in 18301840, executions in Dakota in 1862, massacres of the year 1864 and 1868, and anti-Indian provocation from 1880-1890, resulted in the emergence of a deep animosity in the hearts of the Indians. They are treated discriminatively as racist acts documented in the story of the novel The Pearl.

Kino and Juana and their baby, Coyotito in the novel The Pearl are Indian families who experienced racist discriminatory acts from white people. They were treated differently from white people as a doctor did not want to treat a Coyotito who was stung by a scorpion because he was a baby from an Indian family. They are seen as poor people who are uneducated, not dignified, and not respected in society. The poverty and suffering of the Indians were witnessed firsthand by John Steinbeck as the author of this novel. He said that at this time, the Indians were in a state of poverty and hunger where they had previously had much food, but their lands were seized and their hunted animals, such as bison were slaughtered by armed hunters. The Indians can only reminisce in the past, staring at the lands that have stood on top of the arrogant rich people's settlements where they had previously settled there peacefully with their children and families.

Since white people in the 1800 s raced into western and southern American regions such as Mississippi, Nevada, Montana, Colorado, Wyoming, Dakota, Idaho, Kansas, Nebraska, California, others, Indians increasingly displaced to the periphery and lived in slums. White people are attracted to occupy Indian lands because their area is fertile for agriculture and cotton plantations. This fact also happened to the condition of the house Kino and other Indian families described in the novel are outside the city of La Paz. Their house is a hut that is not worthy of being said to house human habitation as the conditions described in the novel, "Behind Juana's fire leaped into flame and throw spears of light through the chinks of the brush-house wall and threw a wavering square of light out the door" (Steinbeck, 1962: 3).

The American government took 7.8 million square kilometers of Indian land after the Indian Acts Removal passed in 1812, which was further strengthened by the Dewes Act of 1887. The American government gave the rights to manage 65 hectares of land to each family of white immigrants over the Indian region. The Trail of Tears event is an event in American history that caused many Indians to die because they were forced to leave their hometown hundreds or even thousands of kilometers while walking. As many as 60,000 Indians from the Choctaw, Creek, Cherokee, and others were forced to move by American troops to the western region of Mississippi. Thousands of Indians have died from fatigue, hunger and illness on this tearful journey. 
The massive expulsion of the Indians occurred because of the discovery of many valuable minerals, such as silver, gold, iron, and copper in the western regions of the Rocky Mountains, Appalachian, Black Hills, and others. The Indians were increasingly displaced from their homeland with deplorable social conditions even though the area has been inhabited for many years. This event also happened in the novel, since Kino found a large pearl, white people arranged an evil plan to have the pearl. He felt uneasy because of the terror and intimidation carried out by white people who wanted to rob his pearls.

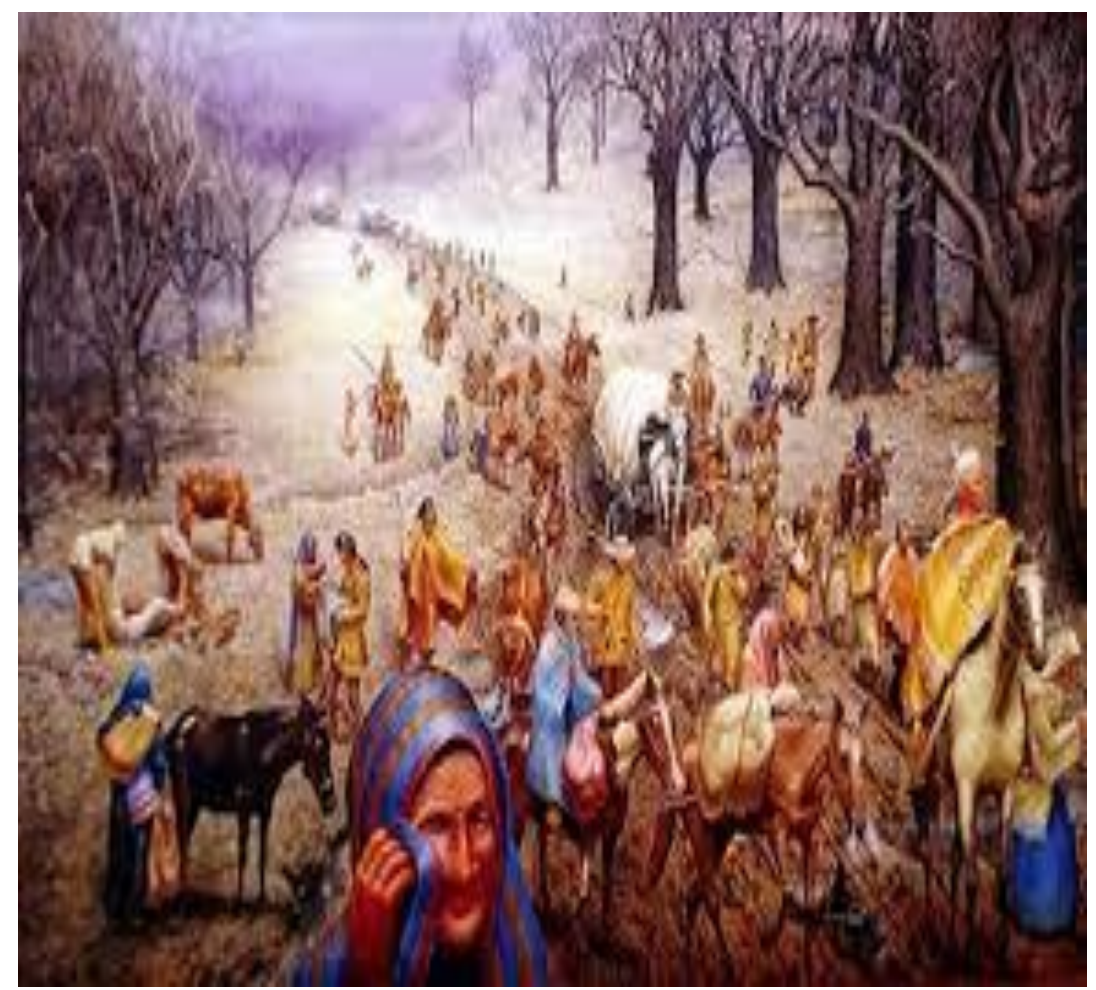

Picture 3. The Indians were forced to leave their settlements where they had to walk thousands of kilometers known as The Trail of Tears in 1831-1877.

(Source: https://www.history.com accessed on April 21, 2020, at 01.21 p.m.)

Mining exploitation made white people wealthy by occupying large and stately homes and luxurious furniture. They built an urban elite that was different from the lives of poor Indians in slums far outside the city. This striking gap resulted in Indians being treated discriminatory and racist moreover they were not given access to education. Kino, in the novel, imagined that if the Indians had an education, then they could not be deceived and he was sure living well. $\mathrm{He}$ aspires that his son will be able to attend school so he can change the situation of the Indians for the better. However, Kino's ideals were not achieved because his son, Coyotito finally died and his pearl was also thrown to the sea floor. The failure of the Indians to realize their ideals was also witnessed by John Steinbeck. $\mathrm{He}$ had worked as a laborer with the Indians and witnessed their suffering in a number of mines in a state of hunger, poverty, misery, and neglect. In another fact, immigrants live in wealth and luxury in cities.

The discriminatory actions of European immigrants against Native Indians 
in America became a racist problem in American history. The universal value that can be obtained from these events is that discriminatory actions and racist thinking must end in building the stability of the American nation and ensuring social justice for all citizens. According to Helen Hunt Jackson (Cineotta, 2004: 216-217) in her book A Century of Dishonor in 1881 requires cultural assimilation between Indians and immigrants as a form of social conflict resolution. However, the idea of assimilation is difficult to realize because of the many differences between Indians and white people, so they find the Indians difficult to fuse. The United States Government in 1924 made another attempt by granting Indian citizenship a statute.

The worldview or vision du monde in the novel The Pearl witnessed directly by John Steinbeck as the author is poverty and loss of rights experienced by the Indians is a fact of humanity that needs to be handled properly and fairly. They also have ideals in advancing their ethnicity, but these ideals are always thwarted by the government's discriminatory policies. The Indians united in the organization of the American Indian Movement in 1968, a movement that demanded the indigenous rights of displaced Indians. The government reviewed its policies towards them, but the ideals of the Indians towards their communal rights and preservation of their culture had not yet been reached until the novel The Pearl was published in 1947.

\section{Conclusion}

Literary work is a work of fiction that has the genetics of social facts so that it has a strong historical aspect in documenting the social facts of a particular society or nation as racist facts in the novel The Pearl by John Steinbeck. This novel reflects racist facts that are discriminatory against Native Americans, namely Indians. The racist facts were revealed in this study using sociological literature analysis. This analysis proves scientifically that imaginative works in the form of literature have universal values that are able to document the social facts that have occurred in society. Therefore the literary works are part of the social documentation of a particular nation or ethnicity. Primary and secondary data analysis methods use the approach of genetic structuralism, a method of literary research that emphasizes the elements of literary structure and the origin of the author's imagination as a social reality.

The situation of poor Indians and displaced people in slums is a social fact witnessed by John Steinbeck as the author of the novel The Pearl through an Indian fictional character named Kino. The conflict between Indians as native people and Europeans as migrants became a major social problem in the history of the American Nation. Since the early arrival of Europeans in America, white people have been involved in conflicts with Indians that began in 1622. Conflict eventually developed into hostility because Indians were treated racist and discriminatory by white people. The Indians were driven out of the land of their ancestors because their land was fertile for agricultural and plantation land and contained valuable minerals in the form of gold, silver, copper, and iron. John Steinbeck as the author believes that poverty and loss of rights experienced by the Indians is a fact of humanity that needs to be handled properly and fairly. 
Literary works need to be examined further from the sociological aspects so that the meaning obtained is more realistic and factual so that the achievement of the essence of literature as a guide to life can be realized. Documentation of facts in fiction teaches humans the need for goodness and ethics. The author suggests that literary researchers conduct genetic exploration in a number of great literary works.

\section{References}

Alberta Civil Liberties Research Centre (ACLRC). (2018, December). Forms of Racism. retrieved from https://www. nationalgeographic.com/magazine/ 2018/12/native-americans-recasting-views-indigenous-life/ (accessed on April 12, 2020)

Al-Hafiz, Afareez Abd Razak. (2012), Misteri Firaun Musuh Para Nabi: menyingkap tabir peradaban paling berpengaruh sepanjang zaman. Translated by Herlina Kamba. Jakarta: Ufuk Publishing House.

Campbell, B.J. (2018, August). The Two Confusing Definitions of Racism. retrieved from https://medium.com/handwaving-freakoutery/the-twoconfusing-definitions-of-racism-2d685d3af845 (accessed on April 12, 2020)

Cineotta, Howard, et al. (2004), Garis Besar Sejarah Amerika. Translated by Yusi A. Pareanom. Jakarta: Departemen Luar Negeri Amerika Serikat.

Endraswara, Suwardi. (2013), Metodologi Penelitian Sastra: Epistemologi, Model, Teori, dan Aplikasi. Yogyakarta: CAPS (Center for Academic Publishing Service).

Faruk. (2014), Pengantar Sosiologi Sastra, dari Strukturalisme Genetik sampai Post-modernisme. Yogyakarta: Pustaka Pelajar.

Goring, Paul, et al (ed.). (2001), Studying Literature: the essential companion. USA: Oxford University Press.

Goldmann, Lucien. (1977), Towards A Sociology of The Novel. London: Tavistock Publications.

Goldmann, Lucien. (1981), Method in the Sociology of Literature. London: Basil Blackwell Oxford.

Larasati, Aziza Fanny. (2019, December). The Two Confusing Definitions of Racism. retrieved from https://www.matamatapolitik. com/historicalgenosida-suku-indian-pembantaian-penduduk-asli-amerika-atas-namaperadaban (accessed on April 15, 2020)

Olson, Keith W. (1992), An Outline of American History. USA: University of Maryland.

Pearson, Michael. (1994), Tempat-Tempat Imajiner. Perlawatan ke Dunia Sastra Amerika. Translated by Sori Siregar, et al. Jakarta: Yayasan Obor Indonesia.

Rahman, Fathu \& Weda, Sukardi. (2018). Students' Perceptions in Appreciating English Literary Works through Critical Comment: A Case Study at 
Hasanuddin University and Universitas Negeri Makassar. Asian EFL Journal. 20. 149-172.

Ramadhan, Farkhan. (2020, February). Konflik Sosial Di Masyarakat. retrieved from https://khanfarkhan.com/contoh-konflik-sosial (accessed on April 12, 2020)

Steinbeck, John. (1962), The Pearl. New York: Bantam Books.

Ratna, Nyoman Kutha. (2013), Paradigma Sosiologi Sastra. Yogyakarta: Pustaka Pelajar. 